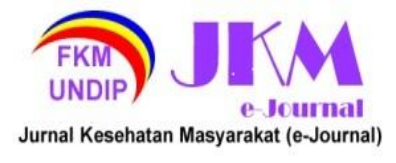

JURNAL KESEHATAN MASYARAKAT (e-Journal)

Volume 9, Nomor 5, September 2021

ISSN: 2715-5617 / e-ISSN: 2356-3346

http://ejournal3.undip.ac.id/index.php/jkm

\title{
PEMETAAN PERSEBARAN KASUS DEMAM BERDARAH DENGUE DI DESA WEDARIJAKSA, KECAMATAN WEDARIJAKSA, KABUPATEN PATI
}

\author{
Adji Bayu Massaid ${ }^{1 *}$, Retno Hestiningsih ${ }^{2}$, M. Arie Wuryanto ${ }^{2}$, Dwi Sutiningsih ${ }^{2}$ \\ ${ }^{1}$ Peminatan Epidemiologi dan Penyakit Tropik, Fakultas Kesehatan Masyarakat \\ Universitas Diponegoro \\ ²Bagian Epidemiologi dan Penyakit Tropik, Fakultas Kesehatan Masyarakat \\ Universitas Diponegoro \\ *Corresponding author: bendoth99@gmail.com
}

\begin{abstract}
DHF is a contagious disease that has become a priority public health problem in Indonesia. DHF is transmitted through female Aedes spp. Carrying the dengue virus in her body. There were 107 cases and one death in Pati Regency, the purpose of this study was to map the distribution of dengue cases and conduct a survey of Aedes spp larvae and determine the type of Aedes spp mosquito vector in the area of dengue cases that died in Wedarijaksa District. This study used a descriptive observational method with a cross sectional research design and was carried out in August - November 2020. The samples of this study were all dengue fever incidence houses in Wedarijaksa Village and houses potentially affected by dengue. From the results obtained, cases have a group pattern and the average larvae are found in the bathtub in the residents' houses. The risk of transmission in Wedarijaksa Village is classified as moderate because $D F>1(D F=3,3), H I>1, B I<50 \%$. All of the mosquito larvae found were Aedes aegypti.
\end{abstract}

Keyword: DHF, Aedes, Wedarijaksa

\section{LATAR BELAKANG}

Demam Berdarah Dengue (DBD) ialah salah satu penyakit menular yang sering meresahkan warga. DBD di tularkan melalui gigitan nyamuk Aedes spp betina yang membawa virus dengue di tubuhnya. ${ }^{1}$ Nyamuk Aedes Prevalensinya yang tinggi dan penyebarannya yang semakin luas menjadikan penyakit ini prioritas masalah kesehatan masyarakat di Indonesia. ${ }^{2}$

Jawa Tengah merupakan salah satu provinsi yang memiliki jumlah kasus dan jumlah kematian akibat DBD tertinggi di Indonesia. Angka kesakitan (IR) DBD di Jawa Tengah pada tahun 2017 sebesar 21,68 per 100.000 penduduk, tahun 2018 sebesar 10,2 per 100.000 penduduk, dan tahun 2019 24,48 per 100.000 penduduk. Angka kematian (CFR) tahun 2017 sebesar $1,24 \%$, tahun 2018 turun menjadi 1,05\%, dan menurun cukup signifikan menjadi $1,03 \%$ di tahun 2019. ${ }^{3}$

Kabupaten Pati merupakan salah satu daerah endemic penyakit demam berdarah dengue di Jawa Tengah. Pada tahun 2017 terdapat 357 kasus dengan 2 kematian, tahun 2018 menjadi 133 kasus dengan 0 kematian, tahun 2019 sebanyak 289 kasus dengan 1 kematian, dan tahun 2020 kasus DBD sudah mencapai 107 kasus dengan 1 kematian. Angka kesakitan (IR) DBD di Kabupaten Pati tahun 2017 sebesar 28,8 per 100.000 penduduk, $2018(10,7$ per 100.000 penduduk), dan 2019 (22,9 per 100.000 penduduk). Angka kematian (CFR) Kabupaten Pati pada tahun 2017 sebesar 0,6\%, mengalami penurunan menjadi $0 \%$ di tahun 2018, dan meningkat menjadi $0,3 \%$ di tahun $2019.4,5$

Terdapat berbagai faktor risiko yang mempengaruhi kejadian Demam Berdarah Dengue seperti faktor lingkungan ataupun faktor host (inang). Faktor lingkungan seperti habitat atau tempat perindukan nyamuk Aedes spp sperti container, dan faktor host seperti perilaku nyamuk Aedes spp yang terjadi perpindahan vector guna mencari breeding place baru. 6,7

Sebagai upaya pengendalian vector penyakit DBD yang lebih efektif dengan melakukan pengendalian pada fase larva dan fase nyamuk dewasa untuk mencegah terjadinya kasus import yang terjadi dalam satu wilayah dapat dilakukan dengan survey secara berkala di rumah warga atau dengan melakukan prediksi jarak terbang nyamuk Aedes spp.,8

Tujuan dilakukan penelitian ini adalah untuk melakukan pemetaan persebaran kasus DBD dan melakukan survey larva Aedes spp serta mengidentifikasi jenis vector nyamuk Aedes spp di wilayah kasus kejadian DBD di Kabupaten Pati. 


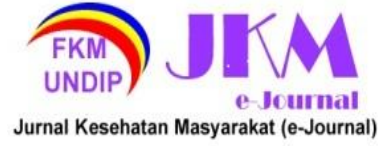

\section{METODE PENELITIAN}

Penelitian ini menggunakan metode deskriptif observasional dengan desain penelitian cross sectional, yang dapat diartikan observasi, dan pengambilan sampel dari variabel penelitian hanya dilakukan sebanyak satu kali pada saat penelitian berlangsung. Penelitian ini dilakukan dari bulan Agustus - November 2020 di wilayah kasus DBD terdapat korban meninggal di Kabupaten Pati, yaitu Desa Wedarijaksa Kecamatan Wedarijaksa.

Populasi dalam penelitian ini terdiri dari dua, yaitu semua kasus DBD di Desa Wedarijaksa pada bulan Januari sampai dengan Juli 2020 sebanyak 3 kasus. Sedangkan populasi untuk survey larva Aedes spp adalah semua rumah di Desa Wedarijaksa. Sampel pemetaan kejadian DBD dalam penelitian ini adalah semua kejadian DBD di Desa Wedarijaksa, sedangkan sampel survey larva Aedes spp terdiri dari jumlah minimal yang dapat mewakili seluruh populasi dengan menggunakan rumus Slovin, dengan rumus:

Keterangan:

$\mathrm{n}$ = Jumlah sampel minimal yang diperlukan

$\mathrm{N}$ = Populasi

$\mathrm{E}=$ Batas toleransi kesalahan pengambilan sampel $5 \%=0,05$

Teknik pengambilan sampel menggunakan teknik random sampling. Penerapan teknik ini dilakukan pengambilan sampel sebanyak 20 rumah, terdiri dari rumah kasus DBD dan 19 rumah sekitarnya dengan jarak radius 50 meter.

\section{HASIL DAN PEMBAHASAN}

Gambaran Umum Lokasi Penelitian

Desa Wedarijaksa merupakan salah satu dari 18 desa yang ada di Kecamatan Wedarijaksa. Rata-rata suhu dari udara yang diukur di Desa Wedarjaksa $28-33^{\circ} \mathrm{C}$. Kelembaban Desa Wedarijaksa yaitu berkisar $72 \%-84 \%$. Terdapat 5 dusun yang ada di Desa Wedarijaksa, yaitu Dusun Jekso, Dusun Demang, Dusun Koki, Dusun Kebon, dan Dusun Bendo. Sebagian besar Desa Wedarijaksa terdiri dari persawahan dan perumahan.

\section{Pemetaan Kasus DBD di Desa Wedarijaksa}

Kasus DBD di Desa Wedarijaksa terdapat 3 kasus dalam satu lingkup desa. Dua dari kasus tersebut terletak di jarak yang berdekatan sedangkan satu kasus lainnya berada di jarak cukup jauh, sehingga output hasil pemetaan dibagi menjadi dua wilayah

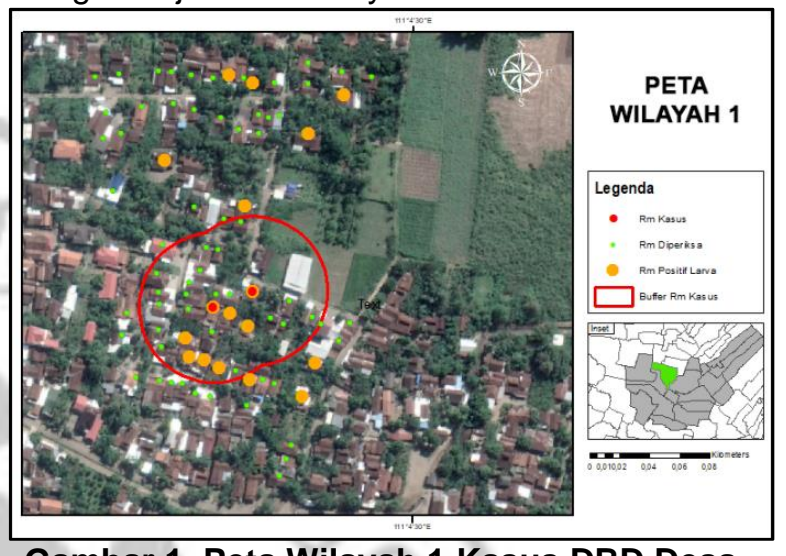

Gambar 1. Peta Wilayah 1 Kasus DBD Desa Wedarjiksa

Berdasarkan Gambar 1, dalam buffer 50 meter terdapat kasus 1 dan kasus 2 yang saling berdekatan dalam satu wilayah buffer. Dalam wilayah buffer 50 meter di temukan sebanyak 8 rumah positif larva termasuk dua rumah kasus DBD dan 9 rumah positif larva berada di luar buffer 50 meter dan 4 diantaranya berdekatan dengan buffer. Berdasarkan gambar 1 menjelaskan bahwa kasus 1 dan kasus 2 terjadi akibat migrasi vector, dan dapat dikategorikan kasus yang memiliki pola berkelompok.

Larva yang ditemukan peneliti rata-rata terletak di dalam rumah di dalam bak mandi rumah warga. Kondisi lingkungan sekitar tempat di temukannya larva memiliki kondisi tidak terang bahkan beberapa rumah berkondisi gelap. Ratarata kelembaban tempat di temukannya larva berkisar $78-82 \%$ dengan suhu rata-rata $31^{\circ} \mathrm{C}$. Berdasarkan perilaku, nyamuk Aedes spp menyukai tempat yang terlindung dari cahaya matahari secara langsung dan memiliki kelembaban tinggi, seperti kamar mandi, dapur, dan kamar tidur. ${ }^{10,11}$ 

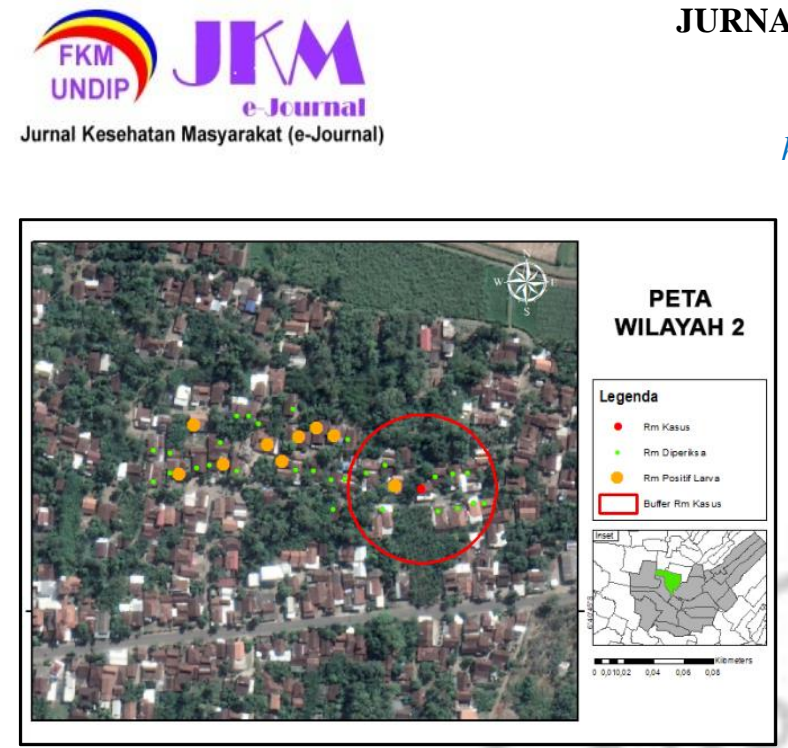

Gambar 2. Peta Wilayah 2 Kasus DBD Desa Wedarijaksa

Berdasarkan gambar 2, dalam satu lingkup wilayah buffer 50 meter hanya terdapat 1 rumah yang positif larva dan letaknya berdekatan dengan rumah kasus. Sedangkan di luar wilayah buffer ditemukan sebanyak 8 rumah positif larva. Larva yang ditemukan di rumah warga berada di bak mandi dalam rumah warga. Kelembaban tempat di temukannya larva memiliki rata-rata $82 \%$ dan suhu rata-rata $31^{\circ} \mathrm{C}$.

\section{Survei Larva Aedes spp}

Survei larva merupakan salah satu metode untuk mengukur populasi larva Aedes spp di suatiu daerah, yaitu dengan memeriksa container atau tempat yang berpotensi menampung air. Survei larva bertujuan untuk mengukur tingkat kepadatan larva suatu daerah yang terdiri dari House Index (HI), Container Index (Cl), Breteau Index (BI), dan ABJ. ${ }^{12}$

Tabel 1. Hasil Survei Larva Desa Wedarijaksa

\begin{tabular}{cccc}
\hline & Rumah & \multicolumn{2}{c}{ Kontainer } \\
\hline $\mathbf{f}$ & (+) Larva & $\mathbf{f}$ & (+) Larva \\
\hline 120 & 26 & 504 & 26 \\
\hline
\end{tabular}

Berdasarkan tabel 1 , survey larva dilakukan dengan metode single larva di Desa Wedarijaksa. Jumlah rumah yang diperiksa 120 rumah dengan total container selama penelitian di Desa Wedarijaksa sebanyak 504 buah dengan memeriksa container yang terletak di dalam dan luar rumah. Larva nyamuk yang ditemukan selama penelitian di Desa Wedarijaksa total sebanyak 26 ekor.
Tabel 2. Indeks Entomologi Desa Wedarijaksa

\begin{tabular}{cccc} 
Indikator & Jumlah (\%) & DF & Keterangan \\
\hline $\mathrm{HI}$ & $\mathbf{2 1 , 6 7}$ & 4 & Sedang \\
$\mathrm{Cl}$ & $\mathbf{5 , 1 6}$ & 2 & Sedang \\
$\mathrm{BI}$ & $\mathbf{2 1 , 6 7}$ & 4 & Sedang \\
$\mathrm{ABJ}$ & $\mathbf{7 8 , 3 3}$ & & \\
\hline
\end{tabular}

Berdasarkan tabel 2, indeks entomologi atau indeks kepadatan larva Aedes spp di Desa Wedarijaksa rata-rata termasuk dalam kategori sedang dengan DF $>1$ atau $\mathrm{DF}=3,3$. Indikator $\mathrm{HI}$ Desa Wedarijaksa sebesar $21,67 \%, \mathrm{Cl}$ sebesar 5,16\%, dan $\mathrm{BI}$ sebesar $21,67 \%{ }^{13}$

ABJ Desa Wedarijaksa sebesar 78,33\%, artinya semakin rendah nilai $A B J$ semakin padat larva di daerah tersebut. Berdasarkan batas minimal departemen kesehatan, ABJ Desa Wedarijaksa terlalu rendah (<95\%). Berdasarkan WHO, nilai indeks entomologi dan ABJ Desa Wedarijaksa memiliki risiko penularan yang tergolong sedang karena $\mathrm{DF}>1, \mathrm{HI}>1(\mathrm{HI}=4)$ dan $\mathrm{BI}<50 \% .{ }^{14}$

\section{Jenis Larva}

Larva yang di temukan Di Desa Wedarijaksa memiliki jenis yang sama, yaitu Aedes aegypti. Identifikasi dilakukan dengan melihat morfologi bentuk dewasa dari sampel larva yang diperoleh dari lapangan.

Aedes aegypti memiliki ciri khusus di golongan nyamuk, ciri khusus utama dalam mengenali golongan Aedes spp adalah warnanya yang hitam dengan bintik putih. Aedes aegypti dan Aedes albopictus sebagian besar morfologinya sama, namun terdapat perbedaan khas yang mencolok pada masing-masing spesies. Perbedaan yang khas terdapat pada punggung nyamuk. ${ }^{15}$

Aedes aegypti memiliki motif lyre, dua garis putih yang melengkung pada bagian tepi dan dua garis lurus putih pada bagian tengah. Aedes albopictus memiliki motif lyre, satu garis putih yang terletak pada tengah-tengah punggung thorax nyamuk. ${ }^{15}$

\section{KESIMPULAN}

Hasil dari observasi yang dilakukan di Desa Wedarijaksa menemukan pola kasus dalam satu lingkup wilayah memiliki pola berkelompok. Saat melakukan kegiatan survey larva Aedes spp didapati data larva rata-rata ditemukan di dalam bak mandi rumah warga, bahkan di rumah kasus 


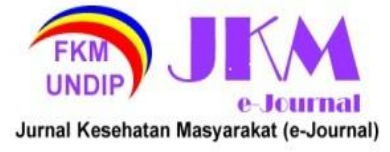

ditemukan keberadaan larva. Desa Wedarijaksa memiliki indicator entomologi sedang atau risiko penularan sedang karena $\mathrm{DF}>1 \quad(\mathrm{DF}=3,3)$ dengan nilai $\mathrm{HI}(21,67 \%), \quad \mathrm{Cl}(5,16 \%), \mathrm{BI}$ $(21,67 \%)$, dan ABJ $(78,33 \%)$. Jenis vector yang berpotensi penyebab DBD di Desa Wedarijaksa adalah Aedes aegypti.

\section{DAFTAR PUSTAKA}

1. Fatati IF, Wijayanto $H$, Sholeh AM. Analisis Regresi Spasial Dan Pola Penyebaran Pada Kasus Demam Berdarah Dengue (Dbd) Di Provinsi Jawa Tengah. Media Stat. 2018;10(2):95.

2. Kementerian Kesehatan RI. Situasi Penyakit Demam Berdarah Dengue Di Indonesia. Infodatin [Internet]. 2017;(1). Available from: https://www.kemkes.go.id/download.php?fil e=download/pusdatin/infodatin/InfoDatinSituasi-Demam-Berdarah-Dengue.pdf

3. Dinas Kesehatan Jawa Tengah. Profil Kesehatan Provinsi Jawa Tengah Tahun 2018 [Internet]. 2019. Available from: https://www.kemkes.go.id/download.php?fil $\mathrm{e}=$ download/pusdatin/profil-kesehatanindonesia/Profil-Kesehatan-Indonesia2019.pdf

4. Pati DKK. Rekapitulasi Kasus DBD Tahun 2017-2020 Kab Pati. Pati; 2020.

5. DKK Pati. Profil Kesehatan Kabupaten Pati Tahun 2018. Pati Dinas Kesehat Kabupaten Pati. 2018;

6. Widyatama EF. Faktor Risiko Yang Berpengaruh Terhadap Kejadian Demam Berdarah Dengue Di Wilayah Kerja Puskesmas Pare. J Kesehat Lingkung [Internet]. 2018;10(4):417-23. Available from: http//ejournal.unair.ac.id/JKL/article/download/510 $7 / 5794$

7. Alifariki LO, Mubarak. Hubungan Karakteristik Kontainer dengan Keberadaan Jentik Nyamuk Aedes aegypti di Wilayah Kerja Puskesmas Poasia Kota Kendari. EIssn. 2017;5(1):388-93.

8. KEMENKES. Demam Berdarah Dengue. Bul Jendela Epidemiol. 2010;2:48.

9. Dirjen P2 dan PL. Buku Saku Penngendalian Deman Berdarah Dengue untuk Pengelola Program DBD Puskesmas. Kementrian Kesehat Republik Indones [Internet]. 2013;1-20. Available from: http://pppl.depkes.go.id/_asset/_download/

\section{Edit Buku DBD.pdf}

10. Perwitasari D, Ariati J, Puspita T. Kondisi Iklim dan Pola Kejadian Demam Berdarah Dengue Di Kota Yogyakarta Tahun 20042011. Media Litbangkes. 2015;243-8.

11. Astuti P, Lustiyati ED. Hubungan Kondisi Lingkungan Fisik Terhadap Tingkat Kepadatan Larva Aedes sp Di Sekolah Dasar Wilayah Kecamatan Kasihan, Bantul, Yogyakarta. J IImu Kesehat Masy. 2018;9(3):216-25.

12. Taslisia T, Rusdji SR, Hasmiwati. Survei Entomologi, Maya Indeks, dan Status Kerentanan Larva Nyamuk Aedes aegypti terhadap Temephos. J Kesehat Andalas [Internet]. 2018;7(1):33-41. Available from: http://jurnal.fk.unand.ac.id/index.php/jka/arti cle/download/777/633

13. Ikawati B, Wahyudi BF, Astuti NT, Sunaryo. Parameter Entomologi pada Daerah Endemis Demam Berdarah Dengue Tinggi dan Rendah di Jawa Tengah (Studi di Kabupaten Kudus dan Wonosobo). Balaba J Litbang Pengendali Penyakit Bersumber Binatang Banjarnegara. 2017;13(1):29-36.

14. Kementerian Kesehatan RI. Riset Implementasi Model Juru Pembasmi Jentik (Jurbastik) dalam Penanggulangan DBD (multicenter 2019) [Internet]. Kementrian Kesehatan Republik Indonesia. 2019. Available from: https://eriset.litbang.kemkes.go.id/download.php?fil $\mathrm{e}=1$. Laporan-2019-Loka Litbang P2B2 Baturaja-RISET IMPLEMENTASI M.pdf

15. Rahayu DF, Ustiawan A. Taksonomi Aedes. Balaba J Litbang Pengendali Penyakit Bersumber Binatang Banjarnegara [Internet]. 2013;9(1):7-10. Available from: http://ejournal2.litbang.kemkes.go.id/index. php/blb/article/download/691/271 